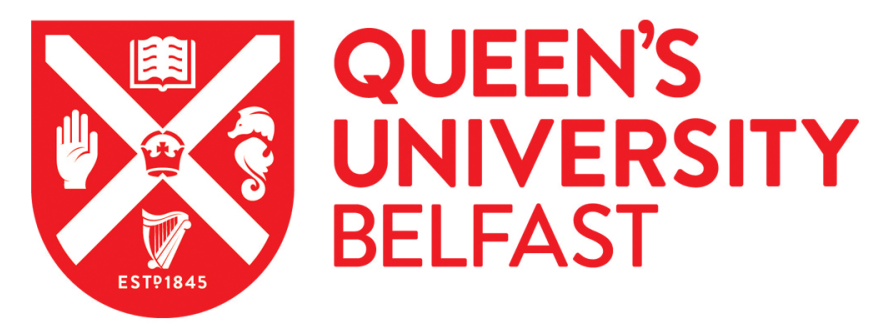

\title{
Relative group size and minority school success: The role of intergroup friendship and discrimination experiences
}

\author{
Baysu, G., Phalet, K., \& Brown, R. (2014). Relative group size and minority school success: The role of \\ intergroup friendship and discrimination experiences. British Journal of Social Psychology, 53(2), 328-349. \\ https://doi.org/10.1111/bjso.12035
}

Published in:

British Journal of Social Psychology

Document Version:

Peer reviewed version

Queen's University Belfast - Research Portal:

Link to publication record in Queen's University Belfast Research Portal

Publisher rights

Copyright 2014, Wiley.

This work is made available online in accordance with the publisher's policies. Please refer to any applicable terms of use of the publisher.

\section{General rights}

Copyright for the publications made accessible via the Queen's University Belfast Research Portal is retained by the author(s) and / or other copyright owners and it is a condition of accessing these publications that users recognise and abide by the legal requirements associated with these rights.

Take down policy

The Research Portal is Queen's institutional repository that provides access to Queen's research output. Every effort has been made to ensure that content in the Research Portal does not infringe any person's rights, or applicable UK laws. If you discover content in the Research Portal that you believe breaches copyright or violates any law, please contact openaccess@qub.ac.uk. 
Relative Group Size and Minority School Success: The Role of Intergroup Friendship and Discrimination Experiences

Gülseli Baysu ${ }^{1}$, Karen Phalet $^{2}$, and Rupert Brown ${ }^{3}$

\author{
${ }^{1}$ Kadir Has University \\ ${ }^{2}$ University of Leuven \\ ${ }^{3}$ Sussex University
}

Word count (exc. figures/tables): 7108

*Requests for reprints should be addressed to Dr. Gülseli Baysu, Kadir Has University, Kadir Has Caddesi Cibali, 34083, Istanbul, Turkey

(e-mail: gulseli.baysu@khas.edu.tr). 


\begin{abstract}
From an intergroup relations perspective, relative group size is associated with the quantity and quality of intergroup contact: more positive contact (i.e., intergroup friendship) supports, and negative contact (i.e., experienced discrimination) hampers, minority identity and school success. Accordingly, we examined intergroup contact as the process through which perceived relative proportions of minority and majority students in school affected minority success (i.e., school performance, satisfaction and self-efficacy). Turkish minorities $(\mathrm{N}=1060)$ were compared in four Austrian and Belgian cities which differ in their typical school ethnic composition. Across cities, minority experiences of intergroup contact fully mediated the impact of perceived relative group size on school success. As expected, higher minority presence impaired school success through restricting intergroup friendship and increasing experienced discrimination. The association between minority presence and discrimination was curvilinear, however, so that schools where minority students predominated offered some protection from discrimination. To conclude, the comparative findings reveal positive and negative intergroup contact as key processes that jointly explain when and how higher proportions of minority students affect school success.
\end{abstract}

Keywords: school success, group size, intergroup contact, discrimination, identity threat, minority 
Perceived Relative Group Size and Minority School Success: The Role of Intergroup Friendship and Discrimination Experiences

Decades after the U.S. Supreme Court's decision in Brown vs. Board of Education (1954), there is still no public consensus on the benefits of social mixing. In Europe, too, the alleged benefits or risks of ethnic diversity in today's classes and schools continue to cause controversy. One example is a recent public debate over informal segregation practices in Belgian primary schools, which were exposed by parents of minority students as discriminatory (“Segregation”, 2010). In Europe, as in the US, the long-term risks to students' life chances associated with ethnically segregated school environments are well documented (Hanuschek, Kain, \& Rivkin, 2009; Kristen, 2005; Massey \& Fischer, 2006; Rumberger \& Palardy, 2005).

Nevertheless, some findings suggest a 'protective aspect' to numerical predominance of minority students (Konan, Chatard, Selimbegovic, \& Mugny, 2010; Portes \& Hao, 2004; Verkuyten \& Thijs, 2002).

This study focuses on Turkish minorities in Austria and Belgium and asks the question 'when' and 'how' relative proportions of minority and majority students in school (i.e., relative group size) affect their school success. Ethnic proportions in schools vary considerably from low minority presence, where there are few minority students, to high presence, where they are the numerical majority. We aim to shed light on the under-researched processes that connect relative group size to school outcomes for minorities (the 'how' question). We argue that school environments with a high minority presence may hamper school success in two ways: through restricting positive experiences of intergroup contact (i.e., intergroup friendship) and through increasing negative experiences of intergroup contact (i.e., discrimination). In light of mixed 
findings on the benefits of social mixing for minorities (Schofield \& Eurich-Fulcer, 2001), an additional research aim is the identification of possible boundary conditions on the psychological costs of a higher minority presence in school (the 'when' question).

Intergroup contact experiences can be more or less frequent, such as when higher minority presence (or lower majority presence) restricts opportunities of minority students for intergroup interaction (Schofield \& Eurich-Fulcer, 2001). From a minority perspective, the experience of intergroup contact can be either positive - spending time or developing friendships with majority peers - or negative - being socially excluded or treated unfairly. Positive and negative experiences of intergroup contact have mostly been investigated separately, and historically the main focus has been on positive contact (Brown \& Hewstone, 2005; Pettigrew \& Tropp, 2006). In parallel, a separate stream of research under the heading of racial aggression and victimisation has addressed negative contact experiences in the context of threat (Graham, 2006; Hanish \& Guerra, 2000; Verkuyten \& Thijs, 2002). However, in ethnically diverse schools, minority students are often exposed to simultaneous positive and negative experiences of intergroup contact.

Drawing on research on identity threat and minority performance (Derks, van Laar, \& Ellemers, 2007), we conceive of positive and negative intergroup contact as sources of identity protection and threat respectively. While negative contact experiences, such as unfair treatment or hostility from teachers or peers, communicate that minority identities are devalued in school (threat), positive contact, such as intergroup friendship, signals that the same identities are accepted by majority group members (protection). Accordingly, we expected that positive intergroup contact would 
support, and conversely, that negative contact experiences would threaten, minority identity and thus success in school.

\section{Intergroup Friendship and School Success}

Culturally diverse school settings may foster positive contact experiences in the form of intergroup friendships (Schofield \& Eurich-Fulcer, 2001). Experimental and longitudinal studies converge on small yet robust associations of positive intergroup contact, and intergroup friendship in particular, with reduced intergroup hostility and prejudice (Allport, 1954; Pettigrew \& Tropp, 2006; Binder et al., 2009; Eller \& Abrams 2004; Levin, van Laar, \& Sidanius, 2003). However, few intergroup contact studies have directly addressed school outcomes for minority groups. There is some evidence that intergroup friendship is positively associated with the school performance of minority students (Graham, Baker, \& Wagner, 1985; Shook \& Fazio, 2008).

From a social identity perspective, we conceive of positive intergroup contact as a chronic source of identity protection (Mendoza-Denton \& Page-Gould, 2008), thus supporting minority performance in 'identity safe' school or work environments (Derks et al., 2007). Social identity protection requires that the school context effectively communicates to minority students that their minority identity is accepted and valued in school (van Laar, Derks, Ellemers, \& Bleeker, 2010). For example, African-American students were more sensitive than White students to the perceived quality of their relationships with other students, which they perceived as diagnostic of their academic value and belonging (Walton \& Cohen, 2007). Reasoning from the identity protection function of positive contact experiences then, intergroup friendship may increase school belonging of minority students (Mendoza-Denton \& Page-Gould, 2008; Shook \& Fazio, 2008), as it signals that the majority group accepts and values diversity (Dixon, Tropp, 
Durrheim, \& Tredoux, 2010). Accordingly, when the majority group values their identity, minority group members are more motivated to perform well (Derks et al., 2007; van Laar et al., 2010).Thus, we hypothesized that intergroup friendship would support the school success of minority group members (H1).

\section{Relative Group Size and Intergroup Friendship}

Opportunities for positive intergroup contact for minority students depend crucially on the school environment, particularly on the relative proportions of minority and majority students in school. School environments where minority students are more numerous than majority students restrict the chances of minority students to encounter majority group friends in school. Conversely, in schools where majority group members are better represented, the chances of intergroup friendship increase (Fischer, 2008; Nesdale \& Todd, 1998; Pettigrew, 1998; Phinney, Ferguson, \& Tate, 1997; Schofield \& Eurich-Fulcer, 2001; Stearns, Buchmann, \& Bonneau, 2009). Importantly, relative group size affects not only the amount of intergroup contact but also intercultural acceptance. In more segregated settings, intergroup friendships are not only less frequent but also less normative (De Tezanos Pinto, Bratt, \& Brown, 2009; McGlothlin \& Killen, 2010). Consequently, we expected that perceptions of higher proportions of minority students in school would restrict intergroup friendship and thus, in turn, would harm minority school success (H2).

\section{Experienced Discrimination and School Success}

Intergroup contact experiences are not always positive. For minorities, more frequent contact with majority group members may also expose them to direct or subtle forms of discriminatory treatment. Such discrimination communicates to minority students the devaluation of their minority identity, and thus poses a threat to their 
identity (Branscombe, Ellemers, Spears, \& Doosje, 1999). Personal experiences of discrimination have been used as indicators of identity threat in a range of intergroup settings (Derks et al., 2007; Purdie-Vaughns et al., 2008; Verkuyten \& Thijs 2002).

Experiences of discrimination in school create a threatening school environment for minority students, who may respond to threat by disengaging from school (GarciaColl et al., 1996). In a longitudinal study of African-American academic outcomes, Mendoza-Denton and his colleagues (2002) showed that past experiences of racial discrimination, through communicating rejection and inducing feelings of threat, interfered with subsequent school performance. Similarly, experimental evidence shows the detrimental effects of identity threat on self-efficacy (Aronson \& Inzlicht, 2004; Cohen \& Garcia, 2005). Finally, Benner and Kim (2009) demonstrated longitudinally the negative impact of past experiences of discrimination on later school adjustment. Accordingly, we expected that past experiences of discrimination in school would hamper the school success of minority group members (H3).

\section{Relative Group Size and Discrimination Experiences}

The degree to which minorities experience discrimination is shaped by the relative group size in a given context (Durkin et al., 2012; Postmes \& Branscombe, 2002). Theoretically, relative group size may confer power and hence be associated with perceived threat on the side of majority group members, especially when a more numerous minority group challenges the dominant position of a majority group (Blalock, 1967; Longshore, 1982; Quillian, 1995).Paradoxically then, minorities may perceive more discrimination in schools with higher minority presence, if majority group members feel more threatened and show more hostility or prejudice in such settings (Longshore, 1982; Quillian, 1995). In a cross-national study of ethnic minority 
youth, higher percentages of immigrants in the national population were associated with more perceived discrimination (Berry, Phinney, Sam, \& Vedder, 2006). Similarly, African Americans in racially segregated environments experienced more discrimination than those in less segregated environments (Postmes \& Branscombe, 2002; Thernstrom \& Thernstrom, 1997). In a recent study on peer victimisation in British schools, ethnic minority children experienced more discrimination in schools with increasing minority proportions (Durkin et al., 2012). In sum, we expected that as the proportions of minority group members in school increased-as reported by minority group members-, so would their experiences of discrimination, which in turn would hamper their school success (H4).

Higher proportions of minority group members may not always lead to increased experiences of discrimination, however (Graham, 2006; Hanish \& Guerra, 2000). It is possible that in highly segregated environments, where minority group members heavily predominate, the effect of further increases in minority group size on real hostile attitudes from majority group members might be negligible. In particular, a 'majority minority' school environment may empower minority group members so that relative numbers would protect them from becoming the target of discrimination. In support of this hypothesis, there is evidence that minorities feel less victimized when they attend schools with many minority peers (Agirdag, Demanet, Van Houtte, \& Van Avermaet, 2010; Graham, 2006; Hanish \& Guerra, 2000; Juvonen, Nishina, \& Graham, 2001; Verkuyten \& Thijs, 2002).

These seemingly contradictory findings suggest that higher proportions of minority group members in school may increase the risk of experiencing discrimination up to a certain point, beyond which negative experiences would not increase further and 
may even be reduced. If this is the case, we should find a curvilinear relationship, specifically an inverted U-shape, between perceived relative group size and experienced discrimination. Some findings hint at curvilinearity without directly testing it. For instance, Portes and Hao (2004) found that in the presence of a sizable percentage of coethnics, disadvantaged minorities, such as Mexican-Americans, were doing better at school than they would do in a mainly White school environment. They interpreted this finding in terms of a potential increase in experienced discrimination in majority White school environments. However, they did not test this assumption. Another study suggesting curvilinearity is that by Longshore (1982). He found support for an inverted U-shaped relationship so that White hostility towards Blacks increased as the proportion of Blacks in school increased up to a certain level (40\%-60\% Blacks), beyond which it started to level off. Finally, Durkin and colleagues (2012) found that minority children experienced more discriminatory aggression (e.g., name-calling and social exclusion due to their skin colour or religion) in schools where they were more numerous. In highly segregated schools with less than $20 \%$ majority pupils, however, the majority pupils reported more discriminatory aggression

\section{The Present Study}

Turkish minorities are a major immigrant minority group in both Belgium and Austria, making up $1.5 \%$ and $2.4 \%$ of the populations respectively. They share similar histories of labour migration and persistent disadvantage in both countries (Heath, Rothon, \& Kilpi, 2008; Herzog-Punzenberger, 2003; citation removed). Belgium and Austria both present an unwelcoming intergroup context with relatively high levels of ethnic inequality and exclusionism (Bail, 2008).

Notwithstanding the similarities of these contexts in terms of the background of 
Turkish minorities, the four cities in Austria and Belgium differ in the perceived and objective proportions of minority students in schools (from low to high overall levels of minority presence: Linz, Vienna, Antwerp, and Brussels). We used a measure of perceived relative group size in this study. Respondents reported retrospectively the proportions of minority to majority students in their primary and (lower) secondary school. The differences between cities in the perceived group size were in line with the objective segregation levels in these cities as reported by other studies (Janssens, Carlier, \& Van De Craen, 2009; Jenkins, Micklewright, \& Schnepf, 2008; Musterd, 2005; Van Kempen, 2003). Respondents also reported retrospectively both positive and negative experiences of intergroup contact in their lower secondary school. In other words, they reported the frequency of intergroup friendship with majority peers and discrimination experiences from peers when they were in 5th to 8th grades.

Overall, the differential relative presence of minority and majority group members in schools and neighbourhoods in Belgium and Austria extend the range of variation of relative group size across the four cities as comparative cases. The comparative part of this study thus allowed us to test the external validity of the proposed effects of perceived relative group size, intergroup friendship and discrimination experiences across four intergroup contexts, with varying levels of objective minority group presence.

Finally, we investigated the effects of perceived relative group size and intergroup contact on both objective and subjective measures of later school success. First we measured objective school performance as the latest educational level achieved: have they achieved higher education, full secondary, or less? Both countries have a hierarchical tracking structure in secondary schools, so that students are typically 
assigned at an early age (10 in Austria, 12 in Belgium) to 'academic' tracks, which prepare them for academic tertiary education, or to 'vocational' tracks, which lead more directly to the labour market. In both countries, relative to majority students, Turkish minority students are typically over-represented in vocational tracks and underrepresented in academic tracks and in tertiary education (citation removed; Heath et al., 2008; Herzog-Punzenberger, 2003). In Europe, in the absence of a standardized grading system, school performance is most reliably measured by differential track placement and dropout status at successive stages of the school career (Alba, Sloan, \& Sperling, 2011). Their final qualifications are thus the closest proxy of school performance. In addition to the objective school performance, we measured minority group members' personal appraisals of their school performance (how satisfied they are with the level of education that they have achieved) and their more general sense of self-competence (how competent they feel they are).

In sum, we asked the question: when and how would higher proportions of minority group members be detrimental for minority school success? We proposed that high minority presence in school would negatively affect minority success through restricting the quantity and quality of intergroup contact. We hypothesized that:

1. Intergroup friendships would have a positive influence on minority school success.

2. Perceptions of higher proportions of minority group members in school would restrict opportunities for intergroup friendship.

3. Experienced discrimination would have a negative effect on minority school success. 
4. Perceptions of higher proportions of minority group members in school would increase the risk of experiencing discrimination.

5. The effects of perceived relative proportions of minority and majority group members on school success would be mediated by intergroup friendship and discrimination experiences.

In addition, we tested whether the association of perceived relative group size with experienced discrimination was curvilinear (inverted U-shape) so that increases in experienced discrimination would level off or even decrease beyond a certain level of minority group presence.

\section{Method}

\section{Participants}

Participants were 1060 local-born members of Turkish minorities in Vienna $(n=$ $252,56.7 \%$ female), Linz ( $n=206,50.5 \%$ female $)$, Antwerp $(n=358,50.3 \%$ female $)$ and Brussels ( $n=244,49.2 \%$ female $)$ in the age range of 18 to $35(M=25 ; S D=4.79)$, who were randomly sampled from the population register (The Integration of European Second Generation Austria, 2008; The Integration of European Second Generation Belgium, 2008). Participants were visited at home by trained interviewers who took computer-assisted personal interviews in Dutch (in Antwerp and Brussels), French (in Brussels) or German (Linz and Vienna). Across cities, the average level of parental education was primary or lower secondary school in Turkey. Twenty-four percent of the participants (27\% in Austria, 22\% in Belgium) were currently students, $49 \%$ had a paid job (46\% in Austria, 52\% in Belgium), and the rest were unemployed or otherwise economically inactive. Among the students, $34 \%$ were following tertiary education, the rest were still in secondary school. Participants were all second generation, i.e., they 
were born in Belgium or in Austria with one or both parents born in Turkey. Perceived proportions of ethnic minority students in secondary school were significantly different across cities, $F(4,1308)=52.49, p<.0001$. Means with a different subscript are significantly different by Tukey's HSD test: $\operatorname{Linz}\left(M_{\mathrm{a}}=2.06, S D=.89\right)$, Vienna $\left(M_{b}=\right.$ $2.29, S D=.87)$, Antwerp $\left(M_{c}=2.71, S D=.86\right)$, and Brussels $\left(M_{d}=3.11, S D=.88\right)$. As expected, the perceived relative group size differences between cities were in line with the objective measures of segregation levels in these cities.

\section{Measures}

School performance. This was measured in terms of final or current educational attainment levels: "What level of education are you attending at present?" for current students, and "to what level of education does your highest diploma correspond?" for others, conditional on entry levels. It was categorized into a three-level ordinal variable: 2 = high (higher education); 1 = medium (upper secondary); $0=$ low (primary, lower secondary and apprenticeship).

School satisfaction. This was measured with one item: "How satisfied are you with the level of education that you have achieved?". Answers were given on a 5-point scale: 1 = completely dissatisfied, 2 = mostly dissatisfied, 3 = neither dissatisfied nor satisfied, $4=$ mostly satisfied, $5=$ completely satisfied .

Self-efficacy. This was a latent factor measured by a short (4-item) version of the self-efficacy scale developed by Schwarzer and Jerusalem (1995). One sample item is, "it is easy for me to stick to my aims and accomplish my goals." The answers were given on a 4-point-Likert scale, ranging from 1= not true at all to $4=$ exactly true. This measure was reliable: $\alpha=.91$ in both cities Belgium and $\alpha=.87$ in both cities in Austria.

Perceived relative group size. This was a latent factor measured by two 
indicators. Participants indicated retrospectively how many children of immigrant origin attended their primary and (lower) secondary school on 5-point Likert scales from $1=$ almost none, $2=$ around 25 percent, $3=$ around half, $4=$ around 75 percent to $5=$ almost all, with higher scores indicating higher proportions of minority students and thus lower proportions of majority students. The two indicators were highly correlated in each city: $r(252)=.67$ in Vienna, $r(206)=.70 \mathrm{in} \mathrm{Linz,} r(358)=.32$ in Antwerp, $r(246)=.63$ in Brussels, all $p=<.001$.

Intergroup Friendships. This was a latent factor measured by two items. Participants were asked how many of their friends were of non-immigrant Belgian/ Austrian origin in their (lower) secondary school. Answers were given on a 5-point scale from $1=$ none, $2=$ very few $3=$ some, $4=$ many to $5=$ most of them. They were also asked to indicate the ethnic background of their best friend in the same period $(1=$ non-minority Belgian/Austrian, $0=$ Turkish as the reference). The two items were significantly correlated in each city: $r(252)=.32$ in Vienna, $r(206)=.61$ in Linz, $r(358)$ $=.44$ in Antwerp, all $p=<.001, r(246)=.15 \mathrm{p}=.02$ in Brussels.

Experienced discrimination. This was a latent factor measured by two items. First, participants indicated how often they personally experienced hostility or unfair treatment from teachers, peers or headmasters in secondary school because of their origin or background. Secondly, participants indicated whether they had ever been confronted with offensive words because of their origin or background at school. Two items were strongly correlated in each city: $r(246)=.60$ in Vienna, $r(205)=.59$ in Linz, $r(358)=.39$ in Antwerp, $r(245)=.41$ in Brussels, all $p=<.001$. Answers were given on 5-point Likert scales from $1=$ never to $5=$ frequently.

Control variables. In order to get net effects of our main predictor variables, we 
controlled for a number of important predictors of school success. Level at entry into secondary school was measured retrospectively: $1=$ academic track, $0=$ vocational track as the reference category. Parental education was measured as a covariate $(0=$ less than primary, $1=$ primary or lower secondary, $2=$ full secondary, $3=$ tertiary level). Gender was dummy coded $(1=$ male, $0=$ female as the reference category $)$. Age and language spoken at home were omitted from the final analysis as they did not have any significant effects. The mean levels for continuous variables and percentages for categorical variables are presented for each city in Table 1.

\section{Data Analysis}

For the purpose of cross-cultural comparison (Davidov, Schmidt, \& Billiet, 2010; Matsumoto \& van de Vijver, 2011), Structural Equation Modeling (SEM) was used to estimate a four-group model with four cities (Vienna, Linz, Antwerp and Brussels) using Mplus 5.21. (Muthén \& Muthén, 2009). All variables were defined as latent factors to correct regression coefficients for unreliability except for school performance and satisfaction, which were measured with one item each. Track at entry, parental education and gender were added as control variables for every variable. As track at entry into secondary school is the main determinant of later school performance, this measure of final school performance conditional on entry level provides a stringent test of the effects of intergroup factors in the school environment. For model modification, comparison, and evaluation, formal indices of global and local fit were complemented with conventional fit indices (Hu \& Bentler, 1999) ${ }^{1}$. In order to test construct validity of the latent factors across four cities, first a common measurement model was specified through Confirmatory Factor Analysis (CFA). Next, control variables and paths were added to the (partially) invariant measurement model. 
Increasingly restrictive equality constraints were imposed on slopes in a stepwise fashion. In the presence of an interaction by city, equality constraints on slopes were rejected on the basis of a significantly worse fit relative to the baseline model $\left(\Delta \chi^{2} \text { test }\right)^{2}$ (Kline, 2005).

In addition, we estimated the same model using the pooled data. In order to test the proposed inverted U-shaped relationship between perceived relative group size and experienced discrimination, we specified a quadratic effect across cities. While a pooled-data analysis is less stringent and reliable than multiple-groups comparative analysis (Davidov et al., 2010), the former is most suitable to extend the range of variation and to identify boundary conditions of generic processes (Matsumoto \& Van de Vijver, 2011). In our case, we aimed to test boundary conditions on a general relative group size-discrimination association by exploiting the full range of variation in relative minority and majority group proportions across the four cities.

\section{Results}

\section{Multiple Group Analysis}

Confirmatory Factor Analysis (CFA). The partially invariant measurement model with perceived relative group size, experienced discrimination, friendship and self-efficacy as latent factors had a good fit: $\chi^{2}(60)=78.01 ; p=.06 ;$ RMSEA $=.03$; CFI $=.97 ; \mathrm{TLI}=.98 \Delta \chi^{2}(21)=20.33 ; p=.50^{3}$. CFA yielded a comparable factor structure across cities, which is the requirement for testing a structural equation model (Matsumoto \& Van de Vijver, 2011). Correlations between friendship and discrimination experiences were negative in Vienna $(r=-.12, p=.005)$, Linz $(r=-.35$, $p<.001)$, Antwerp $(r=-.11, p=.007)$ and positive in Brussels $(r=.09, p=.05)$. 
Structural Equation Model. The final model (see Figure 1) had a good fit ${ }^{4}: \chi$ ${ }^{2}(129)=170.06 ; p=.01 ;$ RMSEA $=.04 ;$ CFI $=.96 ;$ TLI $=.97$. Most hypothesized effects were set equal across cities, which did not yield a significantly worse model fit compared to the unconstrained model $\Delta \chi^{2}(63)=68.12, p=.31$, supporting the presence of similar effects across cities (See Table 2 for the final model specifications for each city). In line with Hypotheses 1 and 2, intergroup friendships increased performance, satisfaction and self-efficacy in every city, and perceptions of higher proportions of minority group members limited the chances of intergroup friendships. In line with Hypothesis 3, experienced discrimination negatively predicted school success, particularly subjective measures of satisfaction and self-efficacy. On performance, it had a significant negative effect only in Linz.

In line with Hypothesis 4, perceptions of higher proportions of minority group members in school increased experienced discrimination but only in Vienna and Linz. This effect could not be set equal across cities, on the basis of a significantly worse model fit, $\Delta \chi^{2}(3)=50.71, p<.001$. Whereas in Vienna and in Linz Turkish minorities who reported higher minority presence in school experienced more discrimination, an opposite pattern was observed in Brussels; that is, higher minority presence decreased experienced discrimination. This unexpected effect could be due to the presence of highly segregated schools in Brussels where the minority group is the local majority. Finally, in Antwerp, perceived relative group size did not have any effect on experienced discrimination and hence this effect was set to zero (See Table 2 for final model specifications).

As for Hypothesis 5, regarding mediation by intergroup friendship and experienced discrimination, we first analyzed the significance of indirect effects using 
Mplus. Most indirect effects of perceived relative group size on school success (through intergroup friendship and experienced discrimination) were significant and replicated across four cities (See Table 3 for indirect effects). Secondly, direct effects of perceived relative group size on school success were no longer significant once experienced discrimination and friendship were added to the model (therefore we set the direct effects of relative group size to zero). This indicates full mediation in line with Hypothesis 5. Specifically, results revealed that the indirect effects of relative group size through intergroup friendship were significant on all measures of school success and replicated across four cities (Table 3). In addition, the indirect effect of perceived relative group size through experienced discrimination was also significant on subjective measures of school success (i.e., satisfaction and self-efficacy) in Vienna and in Linz. Conversely, in Brussels, the significant indirect effects of high minority presence through experienced discrimination on satisfaction and on self-efficacy were positive.

In support of the overall costs of higher minority presence for minority school success, total net effects of higher minority presence on success were mostly negative and never positive (See Table 3 for total effects). Total effects on school performance were always negative, so that minority group members performed less well in more segregated schools where they predominated, everything else being equal. While total effects on school performance were significant and of similar magnitude in all four cities, effects on subjective school outcomes (school satisfaction and self-efficacy) were more variable in Belgium due to stable or somewhat reduced discrimination levels at very high minority presence where they became the local majority. 
Residual correlations between intergroup friendship and discrimination experiences were negative in Linz and Antwerp (with equality constraint across 2 cities, $r=-.11, p=.001)$ and non-significant in Brussels and Vienna. Negative associations between intergroup friendship and discrimination experiences were mostly or wholly explained away after taking into account the variation in perceived relative group size.

\section{Additional Pooled Data Analysis}

In order to test a possible curvilinear association of perceived relative group size with experienced discrimination, the same structural equation model was re-estimated in the pooled data (main effects of city dummies were added to control for between-city variance) and a quadratic effect was added to the model. The model yielded a good global fit, $\chi^{2}(17)=28.33 ; p=.04 ;$ RMSEA $=.03 ; \mathrm{CFI}=.99 ; \mathrm{TLI}=.98$. Both main $(B=$ $.407, s e=.15, p=.007)$ and the quadratic effects of perceived relative group size $(B=-$ $.053, s e=.03, p=.039)$ on experienced discrimination were significant. As seen in Figure 2, minority experiences of discrimination increased as the perceived proportions of minority group members in school increased up to a certain level, beyond which minority experiences of discrimination were somewhat reduced. The tipping point at which experienced discrimination levelled off corresponds to the quadratic equation, $(-0.406) /((2)(-0.053))=3.8$, which indicates a fairly high proportion of minority group members reported on a 5-point scale. Mean perceived levels of relative group size in the four cities are plotted on the $\mathrm{x}$ axis.

Moreover, the figure shows that while in Vienna and Linz around $80 \%$ of minority students attended schools with more than $50 \%$ majority students $(<2.5)$; in Antwerp less than half and in Brussels less than one in four students attended schools with similar percentages of majority students. So most participants in Brussels attended 
schools with moderate (2.5-3.5) to high (>3.5) proportions of minority group members in school. This explains the unexpected negative effect of high minority presence on experienced discrimination in this city. All the other proposed effects were replicated in the pooled data analysis ${ }^{5}$.

\section{Discussion}

The major objective of this study was to investigate the question of when and how the perceived relative proportions of minority and majority students in school affect the school success of minority group members. Taking an intergroup relations perspective on the relative group size of minority students in school, our main research aim was to establish the joint impact of both positive and negative experiences of intergroup contact on the school outcomes of minority group members (the 'how' question). Combining intergroup contact research (Brown \& Hewstone, 2005) with a social identity approach, we reasoned and found that perceptions of higher proportions of minority students would harm minority success through restricting positive contact while simultaneously increasing the risk of negative contact experiences. In addition, in order to identify boundary conditions on the costs of high minority presence (the 'when' question), the same processes were replicated across four distinct intergroup contexts (Vienna, Linz, Antwerp, Brussels) with varying levels of minority presence in schools. We found a curvilinear relationship (i.e., an inverted U-shape) between perceived relative group size and minority experiences of discrimination: Turkish minority group members experienced more discrimination in school as their numbers in school increased up to a point where their numbers approached those of majority group members, beyond which they experienced rather less discrimination.

In discussing our findings, four issues seem to us to be particularly noteworthy. 
First, intergroup friendships proved beneficial for school success of minorities in every city in terms of both objective and subjective measures of school success. This finding fills an important research lacuna since very few studies of intergroup contact have focused on potential protective effects of intergroup contact on the academic performance of minorities (e.g., Shook \& Fazio, 2008). From a social identity approach, our findings underline the importance of intergroup relationship quality for social identity protection in the school environment (Derks et al., 2007; Purdie-Vaughns et al., 2008). In other words, to the extent that the quality of intergroup relations with peers communicates to minority students that their identity is valued, intergroup friends may improve sustained school engagement through enhancing feelings of belonging and acceptance in minority students. Similarly, the acculturation literature has proposed enhanced culture learning and school belonging as potential benefits of intergroup friendships for minority school success (Berry et al., 2006). Majority group friends may facilitate access to culturally grounded knowledge and behavioural repertoires, which are typically valued in the school context and generally lacking in immigrant families (citation removed). Through facilitating language and culture learning, intergroup friendships may support school performance directly as well as indirectly through enhancing the school belonging of minority students (Phinney, Horenczyk, Liebkind, \& Vedder, 2001). Our findings lay the ground for future research, which should test culture learning and school belonging as possible mediating mechanisms between intergroup contact and minority school success.

Second, our findings showed that opportunities for intergroup friendship in school depend crucially on the intergroup composition of the school context. In every city, the relative absence of majority students restricted the chances of intergroup 
friendship. In a similar vein, McGlothlin and Killen (2010) showed that children attending more segregated schools not only considered intergroup friendships as less likely but also evaluated intergroup friendships more negatively compared to children from more diverse schools. In other words, for intergroup friendship, the relative proportions of minority and majority students in school matter.

Third, our findings resonate with studies on identity threat and minority performance in culturally diverse school settings. Identity threat arises when disadvantaged minority students experience direct or vicarious discrimination in school. Converging longitudinal and experimental evidence linking experienced discrimination to performance deficits suggests that identity threat is detrimental for minority school success (Benner \& Kim, 2009; Derks et al., 2007).We found that experienced discrimination was detrimental mainly for subjective measures of school success. Consistent with the literature on more objective measures of school success such as grades or performance, however, the effects of discrimination experiences on minority school performance yielded mixed results. Thus, some studies reported a negative link between experienced discrimination and grades (e.g. Eccles, Wong, \& Peck, 2006); others found no difference (Wong, Eccles, \& Sameroff, 2003). Results with more subjective measures, on the other hand, have more consistently identified a negative association between discrimination experiences and indicators of adjustment in school, such as engagement and self-efficacy (Eccles et al., 2006; Wong et al., 2003).

Finally, our results revealed that perception of increasing proportions of minority students in school was related to increasing experiences of discrimination, but this association was slightly reversed at high levels of minority presence where minority students perceived that they were the local majority. This is a telling finding as it sheds 
light on the mixed research evidence of negative, zero or even positive effects of high minority presence on the school success of minorities (e.g., Konan et al., 2010). Moreover, it throws new light on the mixed research evidence regarding the link between high minority presence and discrimination experiences (Durkin et al., 2012; Graham, 2006; Postmes \& Branscombe, 2002). This finding also clarifies seemingly inconsistent within-city associations between perceptions of higher proportions of minority students and experienced discrimination in our study, which range from negative (Vienna and Linz) through zero (Antwerp) to weakly positive (Brussels). Turkish minorities attend schools where around $25 \%$ of pupils are minority group members in Vienna and Linz; and in these cities, increasing proportions of minority students in school was associated with increasing experiences of hostile or unfair treatment in intergroup encounters with teachers or peers (Durkin et al., 2012; Postmes \& Branscombe, 2002). In Brussels, on the other hand, proportions of minority students in schools were so high $(>50 \%)$ that minority members were no longer the numerical minority in the school context; and in this context, perceived higher minority presence was associated with less experienced discrimination.

Theoretically, this finding is in line with classic studies on threat perceptions by majority members (Blalock, 1967; Blumer, 1958; Longshore, 1982). Accordingly, majority hostility increases with increasing minority group size, because their numbers pose a threat to the dominant position of the powerful majority group ${ }^{6}$. Thus, Quillian (1995) found that the relative size of the immigrant population across 12 European countries explained between-country differences in average prejudice levels. Moreover, Pettigrew and colleagues (2010) showed that perceived threat explained the association of perceived percentages of immigrants with prejudice. None of these studies, though, 
reported a curvilinear relationship. Longshore (1982), on the other hand, reported a curvilinear relationship between majority perceptions of threat and minority presence. He showed that majority feelings of threat were more intense, not when the minority group is highly overrepresented, but when minority and majority groups are roughly of equal size., We also found that in school contexts where minority and majority students are roughly of equal size, minorities experienced most discrimination. In 'majority minority' schools, on the other hand, they experienced less discrimination.

It should also be noted, however, that we did not find a perfect inverted U-shape. In other words, even if minority group members were the local majority in highly segregated schools, they were still feeling discriminated against. Rather, the increase in experiences of discrimination up to $25 \%$ minority presence in school was not paralleled by a similar decrease in experienced discrimination above $75 \%$ minority presence in school. This is probably due to fact that even when minority group members are the local majority, they are aware of their minority status and related group discrimination in society at large (Durkin et al., 2012). Our comparative findings speak to the need for careful consideration of boundary conditions on the harmful effects of school segregation and call for more research on majority minority settings, which are quickly becoming the social reality in many of today's schools.

Looking beyond the processes, however, the total effects of perceived high minority presence and thus low majority presence are always negative for the school performance of minority students: minorities who go to segregated primary and secondary schools are significantly less likely to have an academic school career. Hence, although very high minority presence entails some protection from discrimination, this protective effect never outweighs the opportunity costs of low 
majority presence in terms of restricted positive intergroup contact experiences for minority group members.

We found that intergroup friendship and discrimination experiences are negatively correlated in most cases, which is in line with existing research (Tropp \& Bianchi, 2006). It is also conceivable that, due to their prior negative contact experiences, minority group members may avoid friendships with majority group members. Mendoza-Denton et al. (2002) found that so-called rejection sensitivity associated with past experiences of discrimination among African Americans predicted fewer White friends, more anxiety, and lower academic achievement. Binder et al. (2009) and Levin et al. (2003) found that prejudice longitudinally reduced the amount of intergroup contact, and vice versa. Swart and colleagues (2011) also found support for a bidirectional relationship between contact and prejudice. They showed that intergroup contact at time 1 was negatively associated with intergroup anxiety at time 2 , which, in turn, was negatively associated with prejudice. To further complicate matters, another line of research points to a possible 'downside' of positive intergroup contact for social change in favour of minority group members (Dixon et al., 2010; Saguy, Tausch, Dovidio, \& Pratto, 2009; Wright \& Lubensky, 2008). In particular, positive contact experiences may lead minority members to underestimate real ethnic disadvantage and discrimination.

On this issue we would make two observations. First, our research focus was on minority school success. The same positive contact experiences that help minority members to succeed in school may well undermine their structural awareness and support for collective action. Second, our data are ill-suited to test causal directions in the interplay between positive and negative contact. Yet, both types of experiences 
clearly coexist in real-life intergroup relations: discrimination experiences may discourage cross-group friendship formation; and intergroup friends may lead minority members to discount real discrimination. In our study, negative correlations between friendship and discrimination experiences were mostly explained by opposite effects of perceived relative group size on both types of contact.

Our findings lay the ground for future research, which should further develop a comparative and longitudinal approach to the interplay of ethnic diversity with positive and negative contact experiences and its implications for the success of minorities in multi-group settings. There are also limitations, however. Retrospective data is subject to memory bias. However, we think that such bias is unlikely to invalidate our main findings. On the one hand, retrospective data on behavioural and factual questions, such as the frequency of intergroup friendship at school, yield reasonably reliable information (Blossfeld \& Rohwer, 2002). On the other hand, less successful minority members might retrospectively justify their school failure by overestimating their experiences of discrimination. Our data do not support this reasoning, however, since school performance was unrelated to our discrimination measure. Still, prospective longitudinal data and experimental research would be necessary for establishing the empirical basis for the effects of the quality of intergroup contact on school outcomes.

The perceived relative group size measure in our study has potential limitations. First, it is subjectively reported. The fact that the relative group size is a self-reported measure, however, does not invalidate the findings nor the importance of this measure, as it allows us to capture informal segregation practices in schools (such as at between and within class level) and how it is perceived by minority group members themselves. Moreover, perceived relative group size differences between cities in our study match 
the objective reports of segregation levels in these cities (Janssens, et al., 2009; Musterd, 2005; Van Kempen, 2003). As such, it complements other studies that use more objective measures of relative proportions of minority and majority group members (see Pettigrew at al., 2010). Secondly, fine-grained measures of relative group size would be better suited to differentiate contexts where there are various minority groups from contexts where a single minority group is the numerical majority. Thirdly, as we did not have school-level data and our sample was not drawn in schools either, a multilevel approach was not possible. Future research should ideally include finegrained measures of perceived and objective relative group size both at the individual and school level.

Finally, we should acknowledge that in more segregated schools restricted resources at the level of households or schools may overlap with a lesser quality of intergroup contact. At the level of households, we control for parental education as a key indicator of family-based resources. At the level of schools, we argue that European welfare systems (as distinct from the political economies of the UK and US, for instance) take the edge off public poverty in highly segregated schools. In the Austrian and Belgian educational systems specifically, generous public funding of all schools is supplemented with targeted funding of schools with many children from low-income or immigrant families. Looking beyond material resources, however, school segregation may still overlap with lesser quality of instruction. Future research should therefore include institutional in addition to psychological processes as mediating mechanisms in a multi-level design.

To conclude, this research throws new light on the processes through which high minority presence in school limits minority school success. It sheds light on the virtual 
absence of Turkish minorities from universities in European cities, as it documents how experiences of discrimination in school leads to lower school satisfaction and selfefficacy as well as lower performance in some contexts. It also contributes to existing research on minority school careers and intergroup contact by showing the powerful impact of intergroup friendship for the school success of minorities. Importantly, this study offers useful insights for improving the quality of instruction in multicultural classrooms, as it highlights the protective factors in minority students' experiences of the school environment. Finally, our findings warn against simplistic interventions promoting social mixing without protecting minority identity, which may have the unintended consequence of exposing minority students to more negative intergroup contact experiences. An improved social mixing policy should aim not only at increasing the opportunities for intergroup friendships but also at increasing the resilience of minority students in the face of increased chances of discriminatory treatment. 


\section{References}

Agirdag, O., Demanet, J., Van Houtte, M., \& Van Avermaet, P. (2010). Ethnic school composition and peer victimization: A focus on the interethnic school climate. International Journal of Intercultural Relations, 35(4), 465-473. doi:10.1016/j.ijintrel.2010.09.009.

Alba, R., Sloan, J. \& Sperling, J. (2011). The Integration imperative: The children of low-status immigrants in the schools of wealthy societies. Annual Review of Sociology, 37, 395-415.

Allport, G. W. (1954). The nature of prejudice. Reading, MA: Addison Wesley.

Aronson, J., \& Inzlicht, M. (2004). The ups and downs of attributional ambiguity: Stereotype vulnerability and the academic self-knowledge of African American college students. Psychological Science, 15, 829-836.

Bail, C. A. (2008). The configuration of symbolic boundaries against immigrants in Europe. American Sociological Review, 73(1): 37-59.

Benner, A. D., \& Kim, S. Y. (2009). Experiences of discrimination among chineseamerican adolescents and the consequences for socioemotional and academic development. Developmental Psychology 45(6): 1682-1694.

Berry, J. W., Phinney, S. P., Sam, D. L., \& Vedder, P (Eds.). (2006). Immigrant youth in cultural transition. Acculturation, identity and adaptation across national contexts. New Jersey, London: Lawrence Erlbaum.

Binder, J., Zagefka, H., Brown, R., Funke, F., Kessler, T., Mummendey, A., et al. (2009). Does contact reduce prejudice or does prejudice reduce contact? A longitudinal test of the contact hypothesis amongst majority and minority groups 
in three European countries. Journal of Personality and Social Psychology, 96, 843-856.

Blalock, H.M. (1967). Toward a theory of minority-group relations. New York: Wiley.

Blossfeld, H. P., \& Rohwer, G.. (2002). Techniques of event history modelling: New approaches to causal analysis (2 ${ }^{\text {nd }}$ ed.). New Jersey: Lawrence Erlbaum.

Blumer, H. (1958). Racial prejudice as a sense of group position. Pacific Sociological Review, 1(1), 3-7.

Branscombe, N. R., Ellemers, N., Spears, R.,. \& Doosje, B. (1999). The context and content of social identity threat. In N. Ellemers, R. Spears, \& B. Doosje (Eds.) Social identity, context, commitment, content. Oxford: Blackwell.

Brown v. Board of Education (1954). 347 U.S. 483.

Brown, R., \& Hewstone, M. (2005). An integrative theory of intergroup contact. Advances in Experimental Social Psychology, 37, 255-343.

Cohen, G. L., \& Garcia, J. (2005). I am us: Negative stereotypes as collective threats. Journal of Personality and Social Psychology, 89, 566-582

Davidov, E. , Schmidt, P., \& Billiet, J. (Eds.). (2010). Cross-cultural analysis: Methods and applications. European Association of Methodology Series: Routledge Academic.

Derks, B., van Laar, C., \& Ellemers, N. (2007). The beneficial effects of social identity protection on the performance motivation of members of devalued groups. Social Issues and Policy Review, 1, 217-256.

De Tezanos-Pinto, P., Bratt, C., \& Brown, R. (2010). What will the others think? Ingroup norms as a mediator of the effects of intergroup contact. British Journal of Social Psychology, 49(3), 507-523. 
Dixon, J., Tropp, L. R., Durrheim, K. \& Tredoux, C. (2010). Let them eat harmony: Prejudice reduction strategies and attitudes of historically disadvantaged groups. Psychological Science 19(2), 76-80. doi: 10.1177/0963721410363366.

Durkin, K., Hunter, S., Levin, K. A., Bergin, D., Heim, D., \& Howe, C. (2012). Discriminatory peer aggression among children as a function of minority status and group proportion in school context. European Journal of Social Psychology, $42(2), 243-251$.

Eccles, J. S., Wong, C. A., \& Peck, S. C. (2006). Ethnicity as a social context for the development of African-American adolescents. Journal of School Psychology, 44, 407-426.

Eller, A., \& Abrams, D. (2004). Come together: Longitudinal comparisons of Pettigrew's reformulated intergroup contact model and Common Ingroup Identity Model in Anglo-French and Mexican-American contexts. European Journal of Social Psychology, 34, 229-256.

Fischer, M. J. (2008). Does campus diversity promote friendship diversity? A look at interracial friendships in college. Social Science Quarterly, 89(3), 631-655.

Garcia Coll C., Lamberty G., Jenkins R., McAdoo H.P., Crnic K., Wasik B.H., \& Vázquez Garcia H. (1996). An integrative model for the study of developmental competencies in minority children, Child Development, 67, 1891-1914.

Graham, C., Baker, R., \& Wapner, S. (1985). Prior interracial experience and Black student transition into predominantly White colleges. Journal of Personality and Social Psychology, 47, 1146-1154.

Graham, S. (2006). Peer victimization in school: Exploring the ethnic context. Current Directions in Psychological Science, 15, 317-321. 
Hanish, L.D., \& Guerra, N.G. (2000). The roles of ethnicity and school context in predicting children's victimization by peers. American Journal of Community Psychology, 28, 201-223.

Hanushek, E. A., Kain, J. F. \& Rivkin, S. G. (2009). New evidence about Brown V. Board of Education: The complex effects of school racial composition on achievement. Journal of Labor Economics, 27(3), 349-382.

Heath, A., Rothon, C., \& Kilpi, E. (2008). The Second Generation in Western Europe: Education, unemployment and occupational attainment. Annual Review of Sociology, 34, 211-235.

Herzog-Punzenberger, B. (2003). Ethnic segmentation in school and labour market: 40 year legacy of Austrian guest worker policy. International Migration Review, 37(4): 1120-1144.

Hu, L., \& P. M. Bentler (1999). Cut-off criteria for fit indexes in covariance structure analysis: Conventional criteria versus new alternatives. Structural Equation Modeling, 6(1), 1-55.

Janssens, R., Carlier, D. \& van de Craen, P. (2009). Citizens' forum of Brussels. Education in Brussels. Brussels Studies, 5. Retrieved from http://www.brusselsstudies.be/PDF/EN_73_CFB5.pdf

Jenkins, S., Micklewright, J., \& Schnepf, S. (2008). Social segregation in secondary schools: how does England compare with other countries? Oxford Review of Education, 34(1), $31-37$.

Juvonen, J., Nishina, A., \& Graham, S. (2001). Self-views versus peer perceptions of victim status among early adolescents. In J. Juvonen, \& S. Graham (Eds.), Peer harassment in school: The plight of the vulnerable and victimized (2nd ed., 
pp.105-124). New York: Guilford Press.

Konan, P., Chatard, A., Selimbegovi, L., \& Mugny, G. (2010). Cultural diversity in the classroom and its effects on academic performance: A cross-national perspective. Social Psychology, 41(4), 230-237.

Kline, R. B. (2005). Principles and practice of structural equation modelling (2nd ed.). New York, London: The Guilford Press.

Kristen, C. (2005). School choice and ethnic school segregation. Primary school selection in Germany. Munster: Waxmann.

Levin, S., van Laar, C. Y., \& Sidanius, J. H. (2003). The effects of ingroup and outgroup friendships on ethnic attitudes in college: A longitudinal study. Group Processes and Intergroup Relations, 6, 76-92.

Longshore, D. (1982). Race composition and white hostility - A research note on the problem of control in desegregated schools. Social Forces, 61, 73-78.

Massey, D., \& Fischer, M. (2006). The effect of childhood segregation on minority academic performance at selective colleges. Ethnic and Racial Studies, 29(1), 126.

Matsumoto, D., \& van de Vijver, F. J. R. (2011). Cross-cultural research methods in psychology. Cambridge University Press: New York.

McGlothlin, H., \& Killen, M. (2010). How social experience is related to children's intergroup attitudes. European Journal of Social Psychology, 40(4), 625-634, doi: 10.1002/ejsp.733

Mendoza-Denton, R., Downey, G., Purdie, V. J., Davis, A., \& Pietrzak, J. (2002). Sensitivity to status-based rejection: Implications for African American students' college experience. Journal of Personality and Social Psychology, 83, 896-918. 
Mendoza-Denton, R., \& Page-Gould, E. (2008). Can cross-group friendships influence minority students well-being at historically white universities? Psychological Science, 19(9), 933-9.

Musterd, S. (2005). Social and ethnic segregation in Europe: Levels, causes, and effects. Journal of Urban Affairs, 27(3), 331-348.

Muthén, B., \& Muthén, L. (2009). Mplus [Computer software]. Los Angeles: Muthén \& Muthén Retrieved from http://www.statmodel.com/

Muthén, B., \& Muthén, L. (1998-2007). Mplus user's guide. Los Angeles: Muthén \& Muthén.

Nesdale, D., \& Todd, P. (1998). Intergroup ratio and the contact hypothesis. Journal of Applied Social Psychology, 28(13), 1196-1217.

Pettigrew, T. F. (1998). Intergroup contact theory. Annual Review of Psychology, 49, 6585.

Pettigrew, T. F., \& Tropp, L. R. (2006). A meta-analytic test of intergroup contact theory. Journal of Personality and Social Psychology, 90(5), 751-783.

Pettigrew, T. F., Wagner, U., \& Christ, O. (2010). Population ratios and prejudice: Modelling both contact and threat effects. Journal of Ethnic and Migration Studies, 36(4), 635-650.

Phinney, J. S., Ferguson, D. L., \& Tate, J. D. (1997). Intergroup attitudes among ethnic minority adolescents: A Causal model. Child Development, 68, 955-968.

Phinney, J. S., Horenczyk, G., Liebkind, K. \& Vedder, P. (2001). Ethnic identity, immigration, and well-being: An interactional perspective. Journal of Social Issues 57, 493-510.

Portes, A., \& Hao, L. (2004). The schooling of children of immigrants: Contextual 
effects on the educational attainment of the second generation. Proceeding of National Academy of Science, 101, 11920-27.

Postmes, T., \& Brascombe, N. R. (2002). Influence of long- term racial environmental composition on subjective well-being in African Americans. Journal of Personality and Social Psychology, 83(3), 735-751.

Purdie-Vaughns, V., Steele, C. M., Davies, P. G., Ditlmann, R., \& Randall-Crosby, J. (2008). Social identity contingencies: How diversity cues signal threat or safety for African Americans in mainstream institutions. Journal of Personality and Social Psychology, 94, 615-630.

Quillian, L. (1995). Prejudice as a response to perceived group threat: Population composition and anti-immigrant and racial prejudice in Europe. American Sociological Review, 60, 586-611.

Rumberger, R.W., \& Palardy, G. J. (2005). Does segregation still matter? The impact of student composition on academic achievement in high school. Teachers College Record, 107, 1999-2045.

Saguy, T., Tausch, N., Dovidio, J., \& Pratto, F. (2009). The irony of harmony: Intergroup contact can produce false expectations for equality. Psychological Science, 20, 14-121.

Schofield, J. W., \& Eurich-Fulcer, R. (2001). When and how school desegregation improves intergroup relations. In R. Brown \& S.L. Gaertner (Eds.), Blackwell handbook of social psychology: Intergroup processes (pp. 475-494). Maiden, MA: Blackwell.

Schwarzer, R., \& Jerusalem, M. (1995). Generalized self-efficacy scale. In J. Weinman, S. Wright, \& M. Johnston (Eds.), Measures in health psychology: A user's 
portfolio. Causal and control beliefs (pp. 35-37).Windsor, UK: Nfer-Nelson.

Segregation in school (2010, Sep 17). School in Lokeren zet autochtone kinderen apart.

De Standaard. Retrieved from http://www.standaard.be/artikel/detail.aspx? artikelid=DC2VGLD5

Shook, N. J., \& Fazio, R. H. (2008). Roommate relationships: A comparison of interracial and same-race living situations. Group Processes and Intergroup Relations, 11, 425-437.

Stearns, E., Buchmann, C., \& Bonneau, K. (2009). Interracial friendships in the transition to college: Do birds of a feather flock together once they leave the nest? Sociology of Education, 82, 173-195.

Swart, H., Hewstone, M., Christ, O., \& Voci, A. (2011). Affective mediators of intergroup contact: A three-wave longitudinal study in South Africa. Journal of Personality and Social Psychology, 101(6), 1221-1238. doi: 10.1037/a0024450

The Integration of European Second-Generation Survey Austria (2008). The Institute for European Integration Research and Austrian Academy of Sciences [Data file].

The Integration of European Second-Generation Survey Belgium (2008). Centre for Sociology and Centre for Social and Cultural Psychology University of Leuven [Data file].

Thernstrom, S., \& Thernstrom, A. (1997). America in black and white: One nation, indivisible. New York: Simon Schuster.

Tropp, L. R., \& Bianchi, R. A. (2006). Valuing diversity and intergroup contact. Journal of Social Issues, 62, 533-551.

van Kempen, R. (2003). Segregation and housing conditions of immigrants in Western European Cities. Eurex Lecture 7 on March $13^{\text {th }}, 2003$. Retrieved from 
http://www.shakti.uniurb.it/eurex/ syllabus/lecture7/Lecture7-VanKempen.pdf van Laar, C., Derks, B., Ellemers, N., \& Bleeker, D. (2010). Valuing social identity: Consequences for motivation and performance in low status groups. Journal of Social Issues, 66(3), $602-617$.

Verkuyten, M., \& Thijs, J. (2002). Racist victimization among children in The Netherlands: The effect of ethnic group and school. Ethnic and Racial Studies, $25,310-331$.

Wagner, U., Christ, O., Pettigrew, T. F., Stellmacher, J. \& Wolf, C. (2006). Prejudice and minority proportion: Contact instead of threat effects. Social Psychology Quarterly, 69(4), 380-390

Walton, G. M., \& Cohen, G. L. (2007). A question of belonging: Race, social fit, and achievement. Journal of Personality and Social Psychology, 92, 82-96.

Wong, C. A., Eccles, J. S., \& Sameroff, A. (2003). The influence of ethnic discrimination and ethnic identification on African American adolescents' school and socioemotional adjustment. Journal of Personality, 71,1197-1232.

Wright, S.C., \& Lubensky, M. (2008). The struggle for social equality: Collective action vs. prejudice reduction. In S. Demoulin, J .P. Leyens \& J. F. Dovidio (Eds.), Intergroup misunderstandings: Impact of divergent social realities. (pp. 291310). New York: Psychology Press. 


\section{Footnotes}

${ }^{1}$ The $\chi^{2}$ test is sensitive to sample size. In bigger sample sizes, the following fit indexes are more reliable: comparative fit indexes CFI and TLI (good fit if CFI \& TLI > $.95)$ and the root mean squared error of approximation (good fit if RMSEA $<.05$ ).

${ }^{2}$ Estimation is a diagonally weighted least squares statistic, WLSMV. The chisquare difference testing for this estimation is different from regular chi-square difference tests. The $\chi^{2}$-difference test provided by Mplus was used for model comparison (Muthén \& Muthén, 1998-2007).

${ }^{3}$ Across cities, most loadings were invariant (except for one loading on Intergroup Friendship in Vienna and on relative group size in Linz) as well as most intercepts (except for the intercepts of the best friend indicator in Vienna and Linz).

${ }^{4}$ Chi-Square contributions from each city for the baseline model: 54.82 (Vienna), 53.26 (Linz), 35.01 (Antwerp), 40.04(Brussels); and for the final model: 46.45 (Vienna), 38.10 (Linz), 45.96 (Antwerp), 39.56 (Brussels).

${ }^{5}$ In the pooled data analysis, the results were as follows: high minority presence decreased intergroup friendship $(B=-.61, s e=.17, p=.000)$, while intergroup friendship had a positive effect on school performance $(B=.18$, se $=.07, p=.007)$, satisfaction $(B=.30, s e=.08, p=.000)$ and self-efficacy $(B=.09, s e=.05, p=.042)$. Discrimination decreased school satisfaction $(B=-.43$, se $=.06, p=.000)$ and selfefficacy $(B=-.14$, se $=.04, p=.000)$.

${ }^{6}$ There is some evidence that increasing minority size might increase opportunities for intergroup contact for the majority group members and thus might decrease prejudice (Wagner, Christ, Pettigrew, Stellmacher \& Wolf, 2006). 
Table 1

Descriptive Statistics of Variables in Each City

\begin{tabular}{|c|c|c|c|c|c|c|}
\hline & Vienna & $\operatorname{Linz}$ & Antwerp & Brussels & & \\
\hline & & & & & Pearson $\chi^{2}$ & $\mathrm{p}-$ \\
\hline Percentages & & & & & (df) & value \\
\hline Entry track & & & & & $159.09(3)$ & .000 \\
\hline vocational & $66.5 \%$ & $65.9 \%$ & $31.8 \%$ & $22.4 \%$ & & \\
\hline academic & $34.1 \%$ & $33.5 \%$ & $68.2 \%$ & $77.6 \%$ & & \\
\hline
\end{tabular}

Gender

$3.59(3) \quad$ ns.

$\begin{array}{rrrrr}\text { female } & 56.7 \% & 50.5 \% & 50.3 \% & 49.2 \% \\ \text { male } & 43.3 \% & 49.5 \% & 49.7 \% & 50.8 \%\end{array}$

Best friend

$27.62(3) \quad .000$

$\begin{array}{rrrrr}\text { Turkish } & 80.2 \% & 61.2 \% & 74.6 \% & 80.1 \% \\ & & & & \\ \text { Belgian/Austrian } & 19.8 \% & 38.8 \% & 25.4 \% & 19.9 \%\end{array}$

School Performance

$87.25(6)$

.000

$\begin{array}{rrrrr}\text { low } & 67.5 \% & 62.1 \% & 48.9 \% & 42.5 \% \\ \text { medium } & 27.0 \% & 10.2 \% & 20.7 \% & 30.0 \% \\ \text { high } & 5.6 \% & 10.2 \% & 30.4 \% & 27.5 \%\end{array}$

Within group means (SD)

ANOVA (df)

\begin{tabular}{lcccccr}
\hline Relative group & & & & & & \\
size: Primary & 2.25 & 2.01 & 2.71 & 3.18 & $63.77(3)$ & .000 \\
school & $(0.91) \mathrm{A}$ & $(0.88) \mathrm{A}$ & $(1.13) \mathrm{C}$ & $(.96) \mathrm{D}$ & &
\end{tabular}




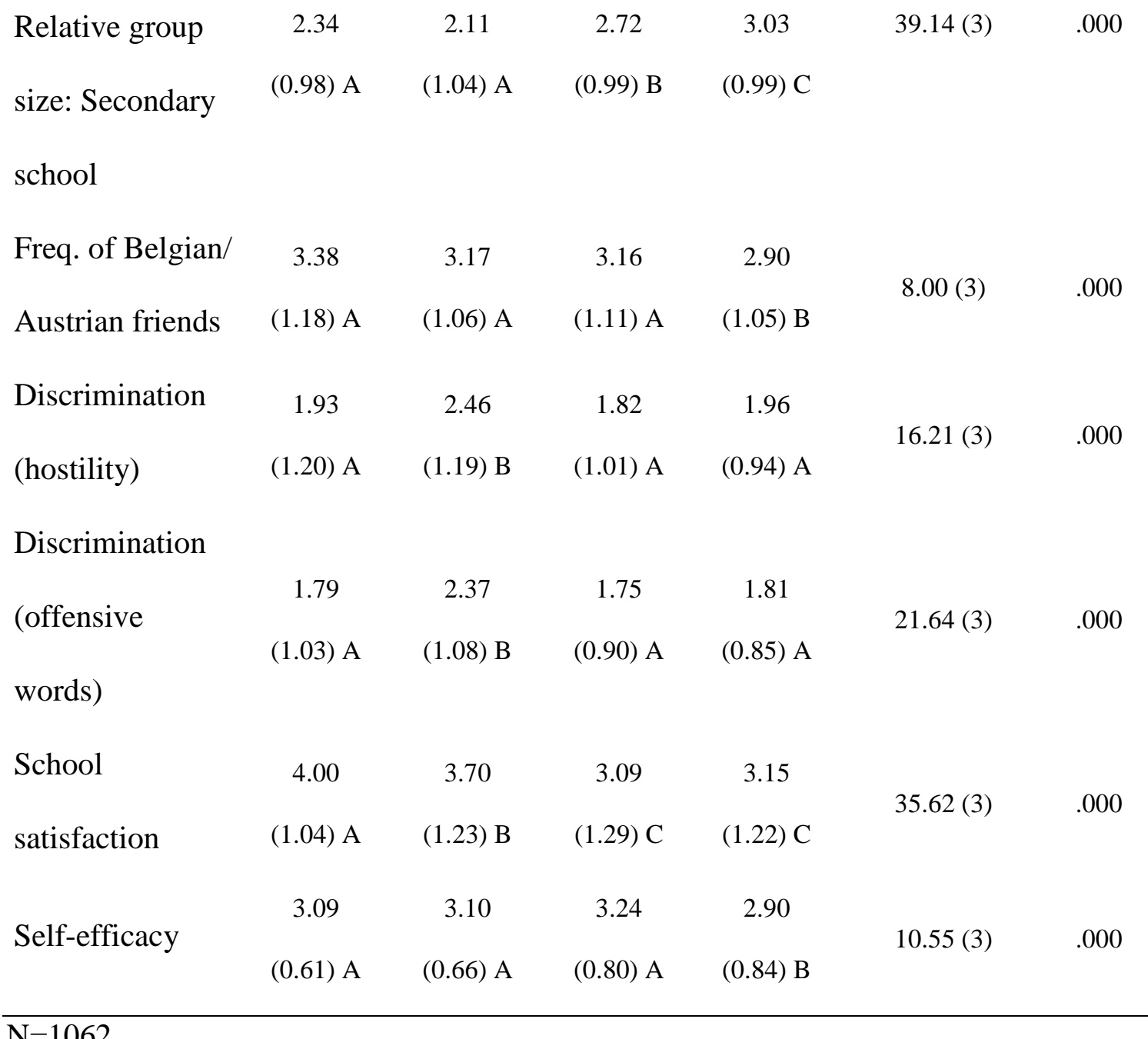


Table 2

Final Model of School Performance, Satisfaction and Self-efficacy in Four Cities:

Unstandardized Parameter Estimates and Explained Variances

Vienna Linz $\quad$ Antwerp $\quad$ Brussels

Effects on relative group size

\begin{tabular}{lcccc}
\hline Track at entry (voc. as ref.) & $-.27(.07)^{* * *}$ & $-.27(.07)^{* * *}$ & $-.27(.07)^{* * *}$ & $-.27(.07)^{* * *}$ \\
Parental education & $-.11(.04)^{* *}$ & $-.11(.04)^{*}$ & $-.11(.04)^{*}$ & $-.11(.04)^{*}$ \\
Gender (woman as ref.) & 0 & $.28(.12)^{*}$ & 0 & 0 \\
\hline Effects on Intergroup Friendship & & & \\
\hline Relative group size & $-.45(.05)^{* * *}$ & $-.45(.05)^{* * *}$ & $-.45(.05)^{* * *}$ & $-.45(.05)^{* * *}$ \\
Track at entry & $.31(.08)^{* * *}$ & $.31(.08)^{* * *}$ & 0 & $.31(.08)^{* * *}$ \\
Parental education & $.15(.04)^{* * * *}$ & $.15(.04)^{* * *}$ & $.15(.04)^{* * *}$ & $.15(.04)^{* * * *}$ \\
\hline Effects on Experienced Discrimination & & & \\
\hline Relative group size & $.40(.07)^{* * *}$ & $.12(.06)^{\mathrm{a}}$ & 0 & $-.18(.05)^{* * * *}$ \\
Parental education & 0 & $-.35(.09)^{* * * *}$ & 0 & 0 \\
Gender & $.24(.06)^{* * * *}$ & $.65(.13)^{* * *}$ & $.24(.06)^{* * * *}$ & $.24(.06)^{* * * *}$ \\
\hline
\end{tabular}

\section{Effects on School Performance}

\begin{tabular}{lcccc}
\hline Relative group size & 0 & 0 & 0 & 0 \\
Intergroup Friendship & $.33(.07)^{* * *}$ & $.33(.07)^{* * *}$ & $.33(.07)^{* * *}$ & $.33(.07)^{* * * *}$ \\
Experienced discrimination & 0 & $-.38(.12)^{* * *}$ & 0 & 0 \\
Track at entry & $.96(.09)^{* * *}$ & $.96(.09)^{* * *}$ & $.96(.09)^{* * *}$ & $.96(.09)^{* * *}$ \\
\hline Effects on School Satisfaction & & & & 0 \\
\hline Relative group size & 0 & 0 & 0 & $.31(.07)^{* * * *}$ \\
Intergroup Friendship & $.31(.07)^{* * *}$ & $.31(.07)^{* * * *}$ & $.31)^{* * *}$
\end{tabular}




\begin{tabular}{|c|c|c|c|c|}
\hline Experienced discrimination & $-.50(.07)^{* * *}$ & $-.50(.07)^{* * *}$ & $-.50(.07)^{* * * *}$ & $-.50(.07)^{* * *}$ \\
\hline Track at entry & $.37(.09)^{* * *}$ & $.37(.09)^{* * *}$ & $.37(.09)^{* * *}$ & $.37(.09)^{* * *}$ \\
\hline Parental education & $.13(.06)^{*}$ & $.13(.06)^{*}$ & $.13(.06)^{*}$ & $.13(.06)^{*}$ \\
\hline Gender & $-.19(.08)^{*}$ & $-.19(.08)^{*}$ & $-.19(.08)^{*}$ & $-.19(.08)^{*}$ \\
\hline \multicolumn{5}{|l|}{ Effects on Self-efficacy } \\
\hline Relative group size & 0 & 0 & 0 & 0 \\
\hline Intergroup Friendship & $.18(.05)^{* * * *}$ & $.18(.05)^{* * *}$ & 0 & $.18(.05)^{* * * *}$ \\
\hline Experienced discrimination & $-.15(.04)^{* * *}$ & $-.34(.07)^{* * *}$ & $-.15(.04)^{* * *}$ & $-.15(.04)^{* * *}$ \\
\hline Track at entry & 0 & $.20(.07) * *$ & $.20(.07) * *$ & $.20(.07) * *$ \\
\hline Gender & 0 & $.23(.09) *$ & 0 & 0 \\
\hline \multicolumn{5}{|l|}{ Explained variances } \\
\hline Intergroup Friendship & .50 & .26 & .21 & .85 \\
\hline Experienced discrimination & .19 & .32 & .06 & .18 \\
\hline School Performance & .26 & .43 & .24 & .20 \\
\hline School Satisfaction & .37 & .36 & .14 & .11 \\
\hline Self-efficacy & .11 & .34 & .02 & .03 \\
\hline
\end{tabular}


Table 3

Direct, Indirect and Total Effect of Perceived Relative Group Size

\begin{tabular}{lllll}
\hline Predictor & \multicolumn{3}{c}{ Relative group size } \\
\hline Cities & Vienna & Linz & Antwerp & Brussels
\end{tabular}

\section{Dependent variables}

\section{School performance}

Direct effect

0

0

0

0

Indirect via Friendship

$$
-.15(.03)^{* * * *} \quad-.15(.03)^{* * * *}-.15(.03)^{* * * *} \quad-.15(.03)^{* * * *}
$$

Indirect via Discrimination

$0 \quad-.05(.03)$

0

0

Sum indirect effect

$$
\begin{array}{llll}
-0.15(.03)^{* * *} & -.20(.04)^{* * * *} & -0.15(.03)^{* * *} & -0.15(.03)^{* * *} \\
-0.15(.03)^{* * *} & -.20(.04)^{* * *} & -0.15(.03)^{* * *} & -0.15(.03)^{* * *}
\end{array}
$$

Total effect

\section{School satisfaction}

Direct effect

0

0

0

0

Indirect via Friendship

$$
-.14(.03)^{* * *}
$$$$
-.14(.03)^{* *}
$$$$
-.14(.03)^{* * *}
$$

$-.14(.03)^{* * * *}$

Indirect via Discrimination

$$
-.20(.04)^{* * *}
$$

$-.06(.03)^{\mathrm{a}}$

0

$.09(.03)^{* *}$

Indirect effect

$$
-0.34(.05)^{* * *}
$$

$-.20(.04)^{* * *}$

$-.14(.03)^{* * * *}$

$-.05(.04)$

Total effect

$$
-0.34(.05)^{* * * *}
$$

$-.20(.04)^{*}$

$-.14(.03)^{* * *}$

$-.05(.04)$

\section{Self-efficacy}

Direct effect

0

0

0

0

Indirect via Friendship

$$
-.08(.02)^{* * *}
$$

$-.08(.02)^{* * *}$

0

$-.08(.02)^{* * *}$

Indirect via Discrimination

$$
-.06(.02)^{* *}
$$

$-.04(.02)^{\mathrm{a}}$

0

$.03(.01)^{* *}$

Sum indirect effect

$$
-.14(.03)^{* * *} \quad-.12(.03)^{* * *}
$$

0

$-.05(.02)^{*}$

Total effect

$-.14(.03)^{* * *}$

$-.12(.03)^{* * *}$

0

$-.05(.02)^{*}$ 


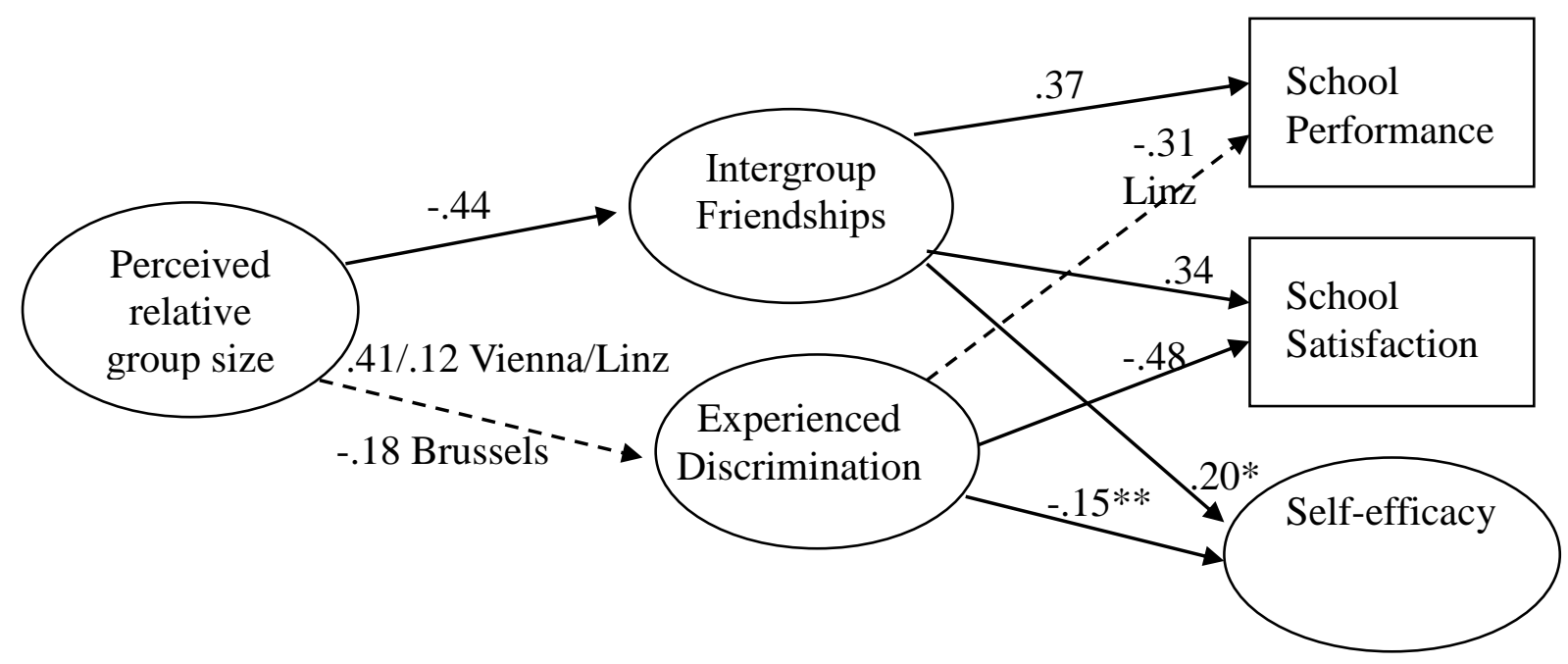

Figure 1. The effects of perceived relative group size, intergroup friendship and discrimination experiences on school performance satisfaction, and self-efficacy in Vienna, Linz, Antwerp and Brussels.

Note. Bold lines indicate the effects that are set equal across cities. Squares are used for observed variables and ellipses are used for latent variables. A city name next to a coefficient indicates the presence of the effect only in that city.

* This effect is not observed in Antwerp

** This effect is different in Linz: -.32 


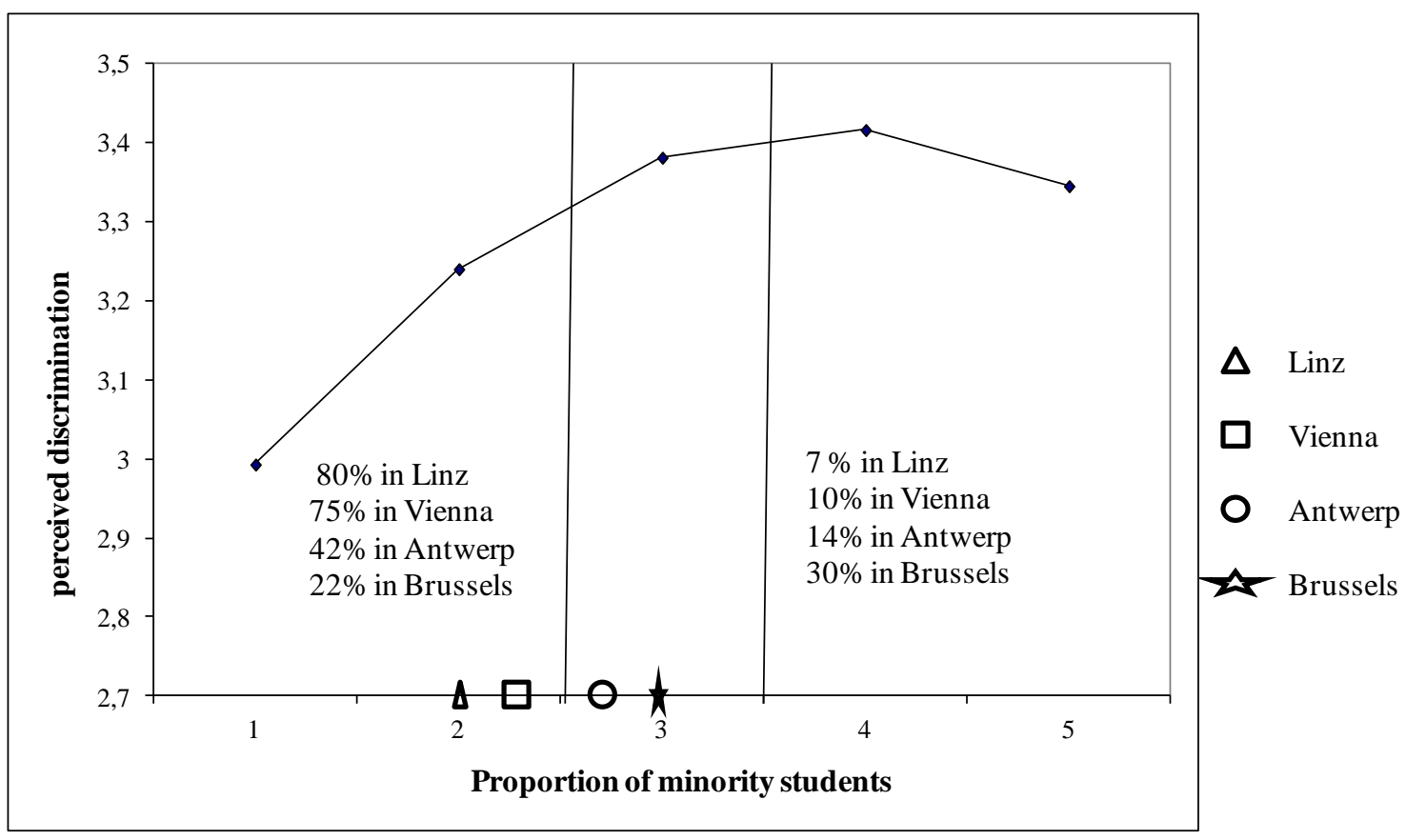

Figure 2. The curvilinear relationship between perceived relative group size and experienced discrimination across cities.

Note. The markers on the $\mathrm{x}$-axis indicate mean levels of perceived relative group size in different cities. The percentages on the left-hand-side show the percent of minority participants in each city attending schools where minority group members constitute less than $50 \%(<2.5)$ of the school population. Percentages on the right-hand-side indicate the percentages of minority participants in each city attending schools where minority group members constitute more than $50 \%(>3.5)$ of the school population. 